\title{
AKSESIBILITAS ANAK MENGIKUTI PENDIDIKAN ANAK USIA DINI DI KABUPATEN SUMEDANG
}

\author{
Nugrahana Fitria Ruhyana \\ e-mail: nugrahana@gmail.com \\ Bappelitbangda Kabupaten Sumedang \\ JI. Prabu Gajah Agung No.9 Sumedang, Jawa Barat, 45252
}

\begin{abstract}
Abstrak: Usia dini merupakan periode penting dalam pembentukan manusia. Manfaat jangka panjang mengikuti pendidikan anak usia dini adalah meningkatnya peluang anak untuk dapat menyelesaikan sekolah sampai pendidikan tinggi yang berdampak pada tingkat kesejahteraan yang lebih baik di masa yang akan datang. Di Kabupaten Sumedang yang menjadi lokasi penelitian ini, partisipasi anak mengikuti pendidikan anak usia dini masih belum optimal. Sekitar $47 \%$ dari jumlah anak usia $4-6$ tahun belum mengikuti pendidikan anak usia dini. Oleh karena itu perlu diketahui faktor-faktor yang memengaruhi aksesibilitas anak dalam mengikuti pendidikan anak usia dini di Kabupaten Sumedang. Hal ini untuk mencari alternatif kebijakan agar aksesibilitas anak usia dini untuk bersekolah dapat ditingkatkan. Penelitian ini dilaksanakan pada tahun 2017 dengan menggunakan metode kuantitatif. Data diperoleh dari Susenas Tahun 2015 dengan responden sebanyak 300 anak. Analisis data dilakukan menggunakan regresi logistik dengan bantuan software STATA versi 12. Hasil penelitian menemukan bahwa aksesibilitas anak di Kabupaten Sumedang untuk mengikuti pendidikan anak usia dini ditentukan oleh pendidikan kepala rumah tangga, status pernikahan orang tua, pendapatan rumah tangga, jumlah anggota rumah tangga, dan domisili anak. Edukasi tentang pentingnya pendidikan anak usia dini bagi para orang tua berpendidikan rendah dan perluasan sarana prasarana sekolah untuk anak usia dini, khususnya di wilayah pedesaan Kabupaten Sumedang, masih perlu ditingkatkan untuk menghasilkan sumber daya manusia yang lebih baik di masa yang akan datang.
\end{abstract}

Kata-kata kunci: aksesibilitas, anak, pendidikan anak usia dini, rumah tangga

\section{THE CHILDREN'S ACCESSIBILITIES TO PARTICIPATE IN THE EARLY CHILDHOOD EDUCATION PROGRAMS IN SUMEDANG REGENCY}

\begin{abstract}
The early age is a substantial period in human development. The long-term benefit from participating in the early childhood education programs is increasing opportunities for the children to complete their higher education in order to get the better welfare future. In Sumedang regency - the location of this study - the children's participations in joining the early childhood education programs had not been optimized yet. Approximately 47\% of the children aged 4-6 years had not participated in the early childhood education programs yet. Thus, it was significant to seek out the factors influencing the children's accessibilities to participate in the early childhood education programs in Sumedang regency in order to find out the alternative policy to increase their accessibilities to participate in the early childhood education programs. The research was conducted in 2017 using the quantitative method. The data were obtained from the "2015 Susenas" which involved 300 respondents. The data analysis was performed by using the logistic regression with the 12th version of STATA software. The findings showed that the children's accessibilities to participate in the early childhood education programs in Sumedang regency was determined by the educational background of the head of family, the marital status of the parents, the head of the family's income, the number of the family members, and the children's domicile. Giving knowledge about the importance of early childhood education to the lower educational background parents and enlarging the early childhood schools' facilities and infrastructures especially in rural areas of Sumedang regency still needed to be improved in order to have better human resources in the future.
\end{abstract}

Keywords: accessibilities, children, early childhood education programs, family 


\section{PENDAHULUAN}

Sumber daya manusia merupakan modal dasar pembangunan yang paling berharga. Kebangkitan dan kemunduran suatu bangsa lebih banyak ditentukan oleh sumber daya manusia dibandingkan faktor lainnya. Coleman (1988) menggambarkan modal sosial (social capital) berperan dalam menciptakan modal manusia (human capital) dengan cara memperlihatkan apa yang berlangsung dalam keluarga dan masyarakat dalam proses perkembangan pendidikan anak-anak (Syahra, 2003).

Todaro \& Smith (2011) mengemukakan bahwa pendidikan adalah input (masukan) bagi fungsi produksi nasional dalam perannya sebagai komponen modal manusia (human capital), yang berarti investasi produktif dalam sumber daya manusia. Melihat pada perkembangan pendidikan, baik di Indonesia maupun di dunia internasional, terdapat tujuan atau keinginan yang sama yaitu memajukan bidang pendidikan tanpa membedakan gender dalam arti laki-laki dan perempuan mempunyai hak yang sama sehingga faktor pendidikan menjadi kebutuhan yang sangat mendasar bagi semua pihak tanpa pengecualian (Warsilah, 2017). Hal ini menjadi indikasi penting bahwa pendidikan yang menjadi hak warga negara harus bersifat inklusif dan dapat diakses oleh semua lapisan masyarakat.

Begitu pentingnya edukasi atau pendidikan bagi kemajuan suatu bangsa yang dapat diukur secara kuantitatif dari indeks pendidikan, telah memacu negara-negara di dunia berlomba-lomba meningkatkan kualitas sumber daya manusia. Indikator yang digunakan untuk mengukur keberhasilan pembangunan manusia adalah Indeks Pembangunan Manusia (IPM).

Berdasarkan data Human Development Report tahun 2015, peringkat IPM Indonesia masih berada pada peringkat 110 dari 188 negara (UNDP, 2015). Jika dikaitkan dengan daya saing maka menjadi tantangan berat bagi Indonesia untuk mengejar ketertinggalan dari negara lain. Komponen IPM secara umum di Indonesia yang nilainya paling rendah ada pada indeks pendidikan dibandingkan dengan indeks kesehatan dan indeks pengeluaran.

Hal ini terjadi juga di tingkat provinsi maupun kabupaten/kota, dimana indeks pendidikan merupakan komponen dengan nilai terendah. Penelitian ini bermaksud menelaah kondisi pendidikan di salah satu kabupaten di Provinsi Jawa Barat, yaitu Kabupaten Sumedang. Kondisi IPM di Kabupaten Sumedang menunjukkan hasil bahwa indeks pendidikan masih lebih rendah capaiannya dibanding indeks lainnya. Hal ini menjadi indikasi bahwa peningkatan aspek pendidikan merupakan langkah strategis bagi kemajuan masyarakat di Kabupaten Sumedang.

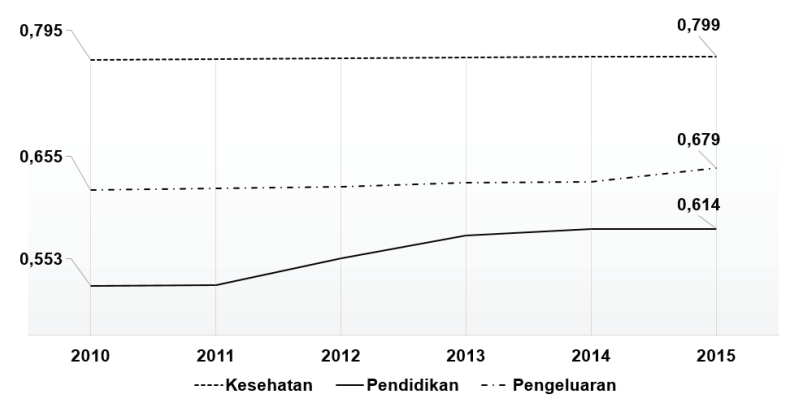

Gambar 1. Tren komponen IPM Kabupaten Sumedang (BPS, 2016a)

Tantangan lebih besar tidak hanya prestasi IPM yang cukup memprihatinkan, namun juga moralitas generasi muda bangsa ini. Lepasnya nilai agama, norma, dan budaya luhur bangsa ini seiring dengan arus liberalisasi telah menyebabkan ancaman serius bagi dekadensi moral di kalangan generasi muda, termasuk anak-anak yang paling rentan dengan pengaruh budaya peradaban liberal.

Menurut Musyarofah (2014), persoalan dekadensi dan demoralisasi begitu kompleks dihadapi bangsa ini. Pendidikan anak usia dini dengan misi utama meletakkan dasar-dasar pengembangan fisik, moral, intelektual, dan spiritual anak memberi peluang besar sebagai solusi persoalan tersebut.

Pemberian rangsangan yang tepat pada anak akan mampu membentuk sosok pribadi yang baik secara intelektual dan moral. Usia dini merupakan masa emas (the golden age) bagi perkembangan anak. Pada usia tersebut segenap aspek perkembangan anak termasuk kecerdasan sedang pesat terjadi. Banyak ahli menyatakan bahwa perilaku orang dewasa sangat dipengaruhi masa kecilnya. Usia di bawah lima tahun adalah usia 
paling kritis yang menentukan dalam pembentukan karakter dan kepribadian seseorang (Musyarofah, 2014).

Hasil penelitian Yoshikawa et al., (2013) membuktikan bahwa program-program pendidikan anak usia dini umum mempunyai dampak yang signifikan untuk proses pembelajaran anak, khususnya perkembangan sosial emosional dan kesehatan. Sementara manfaat jangka panjang bagi anak yang mengikuti pendidikan anak usia dini, yaitu peluang anak-anak dapat menyelesaikan sekolah sampai pendidikan tinggi semakin besar yang berarti tingkat kesejahteraan mereka di masa yang akan datang bisa lebih baik.

Para pakar pendidikan di dunia telah membuktikan pentingnya pendidikan anak usia dini. Kehadiran anak pada pendidikan anak usia dini berpengaruh positif pada kontrol diri anak di tingkat sekolah dasar yang diukur dari tingkah lakunya seperti konsentrasi, kerja keras, partisipasi di kelas, dan disiplin (Berlinski, Galiani, \& Gertler, 2006).

Kajian dari berbagai sudut pandang medisneurologis, psikososial-kultural, dan pendidikan mengimplikasikan suatu pandangan yang komprehensif tentang anak usia dini. Secara singkat, kajian tersebut menyimpulkan bahwa anak usia dini (sejak lahir hingga 6 tahun) adalah sosok individu makhluk sosial kultural yang sedang mengalami suatu proses perkembangan yang sangat fundamental bagi kehidupan selanjutnya dengan memiliki sejumlah potensi dan karakteristik tertentu (Abdulhak, 2003).

Menurut Rahman (2005), anak yang mendapatkan pembinaan sejak usia dini akan dapat meningkatkan kesehatan dan kesejahteraan fisik dan mental, yang secara langsung maupun tidak langsung akan berdampak pada peningkatan prestasi belajar, etos kerja, dan produktivitas. Pada akhirnya, anak akan lebih mampu untuk mandiri dan mengoptimalkan potensi yang dimiliki.

James Heckman, ekonom pemegang hadiah Nobel dari Universitas Chicago, menjelaskan dengan gamblang sedemikian pentingnya melakukan investasi modal manusia pada usia dini (0-3 tahun) mengingat return on investment-nya lebih tinggi dibandingkan investasi-investasi yang menargetkan anak di usia yang lebih tua atau dewasa (Yusuf, 2017). Usia 0-3 tahun adalah usia yang sangat sensitif dalam perkembangan otak anak (Gambar 2), baik itu terkait dengan hal-hal kognitif seperti pemahaman angka, simbol, maupun social skills.

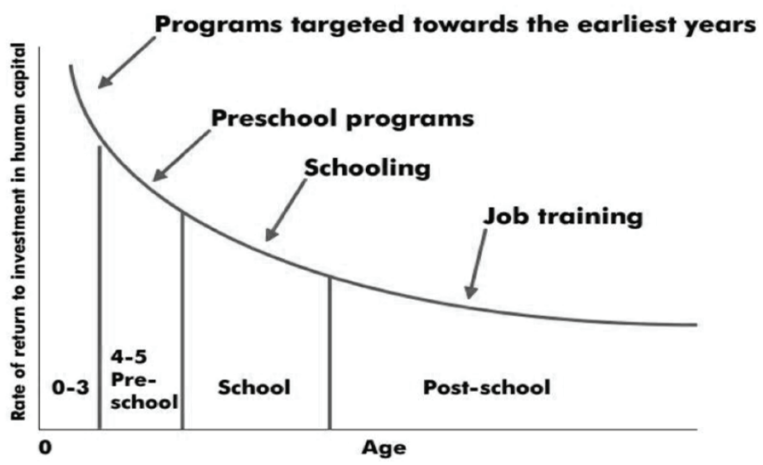

Gambar 2. Tingkat pengembalian investasi pada modal manusia (Heckman, 2014)

Disahkannya Undang-undang Nomor 20 Tahun 2003 tentang Sistem Pendidikan Nasional yang secara eksplisit mencantumkan tentang pendidikan anak usia dini/PAUD (Pasal 28), menunjukkan adanya komitmen bangsa Indonesia untuk menempatkan pendidikan anak usia dini sebagai bagian penting dalam penyiapan sumber daya manusia di masa mendatang sebagai modal manusia untuk membangun negeri menjadi lebih baik.

Menurut Biechler dan Snowman (1993), sebagaimana dikutip oleh Patmonodewo (2003), usia anak untuk mengikuti pendidikan anak usia dini adalah yang berusia antara 3-6 tahun. Di Indonesia, umumnya mengikuti program tempat penitipan anak (3 bulan -5 tahun) dan kelompok bermain (usia 3 tahun), sedangkan pada usia 4-6 tahun biasanya mengikuti program taman kanak-kanak.

Perkembangan pendidikan anak usia dini di Kabupaten Sumedang hingga tahun 2015 berdasarkan profil daerah Kabupaten Sumedang, terdapat lembaga pendidikan anak usia dini sebanyak 674 satuan yang tersebar di 26 kecamatan, jumlah penduduk usia 4-6 tahun yang merupakan sasaran pendidikan anak usia dini sebanyak 47.935 orang. Namun dari jumlah tersebut yang tertampung pada lembaga pendidikan anak usia dini sebanyak $52,90 \%$ sehingga masih ada $47,10 \%$ anak yang belum/tidak mengakses pendidikan anak usia dini (Bappeda Kab. Sumedang, 2015). Kondisi ini tidak banyak mengalami perubahan, karena di tahun 2017 angka partisipasi sekolah anak usia $4-6$ tahun di Kabupaten Sumedang berada pada $57,62 \%$ (Kemdikbud, 2017).

Masih rendahnya partisipasi anak mengikuti 
pendidikan usia dini mengindikasikan masih terbatasnya aksesibilitas anak usia dini untuk mendapat pendidikan usia dini secara formal. Menurut Carneiro (dalam Perdana, 2015), bahwa ada dua perlakuan aksesibilitas, yaitu aksesibilitas keuangan yang diartikan sebagai "kemampuan individu", seperti kemampuan membayar biaya pendidikan, dan apa saja yang berhubungan dengan aksesibilitas fisik, seperti transportasi dan waktu.

Perdana (2015) mengemukakan bahwa menurut teori Liberal Klasik, setiap orang dilahirkan dengan jumlah kapasitas tertentu yang sebagian besar diwariskan dan tidak dapat diubah secara substansial. Dengan demikian, sistem pendidikan harus dirancang sedemikian rupa untuk menghilangkan hambatan apa pun termasuk faktor alamiah/takdir anak-anak yang melekat pada dirinya (latar belakang ekonomi orang tua, jenis kelamin, jumlah anggota keluarga, dan geografis/ keadaan lingkungan) yang dapat menghambatnya memperoleh pendidikan.

Hal di atas sejalan dengan temuan Majzub \& Rashid (2012) bahwa keterbatasan akses pendidikan bisa disebabkan oleh banyak faktor seperti latar belakang keluarga, keterlibatan orang tua, interaksi orang tua dengan anak, berpengaruh terhadap kesiapan anak untuk bersekolah. Sementara itu, Mike, Nakajjo, \& Isoke (2008), dalam penelitiannya menemukan bahwa faktor pendidikan orang tua, jumlah anggota rumah tangga, dan pendapatan rumah tangga berpengaruh terhadap kemungkinan siswa untuk tidak melanjutkan sekolah.

Secara khusus, keterbatasan ekonomi keluarga sering kali menjadi masalah utama yang menghambat akses anak-anak untuk memasuki jenjang pendidikan, termasuk pendidikan anak usia dini. Lake (2011), mengemukakan bahwa anak dari keluarga tingkat ekonomi rendah masih memiliki kesempatan yang terbatas untuk mendapatkan pendidikan formal. Jika anak-anak itu tidak berkesempatan mendapatkan pendidikan formal sejak usia dini, kemungkinan kemiskinan dan kesehatan buruk akan mengikuti mereka sampai dewasa. Untuk itu, pemerintah perlu meningkatkan belanja pada sektor pendidikan usia dini dan memberikan kesempatan besar bagi mereka untuk bersekolah.

Engle, et al. (2011) menilai efektivitas intervensi program pemerintah di berbagai negara berpenghasilan rendah dan menengah untuk pengembangan anak usia dini, berpotensi mengurangi ketimpangan yang disebabkan oleh kemiskinan, gizi buruk, dan kesempatan belajar yang terbatas. Bagi negara yang sedang berkembang seperti Indonesia, intervensi pembangunan anak usia dini efektif dalam meningkatkan perkembangan kognitif anak-anak (Rao, Sun, Chen, \& Ip, 2017).

Beberapa penelitian sebelumnya terkait anak usia dini lebih menekankan pada dampak positif dari pendidikan anak usia dini yang semakin membuktikan urgensinya untuk meningkatkan kualitas generasi yang akan datang (Apriana, 2009; Berlinski et al., 2006; Fahmi \& Jewelery, 2015; Heckman, 2014; Yoshikawa et al., 2013, Chen \& Feng, 2013), khususnya di negara berkembang dan terbelakang (Black et al., 2017; Engle et al., 2011; Majzub \& Rashid, 2012; Rao et al., 2017). Namun, penelitian yang mengestimasi faktor-faktor penentu aksesibilitas anak usia dini untuk bersekolah pada level mikro atau rumah tangga belum banyak dilakukan.

Adapun penelitian sebelumnya hanya mengestimasi faktor-faktor tersebut untuk melihat aksesibilitas anak pada usia sekolah (Aristin, 2015; Dewi, Zukhri, \& Dunia, 2014; Finnie \& Mueller, 2008; Mike et al., 2008; Novian Saputra Perdana, 2015), bukan pada anak usia dini. Pada penelitian sebelumnya, beberapa faktor yang secara signifikan berkorelasi positif dengan aksesibilitas anak bersekolah adalah pendapatan orang tua atau pendapatan rumah tangga, pendidikan orang tua, jumlah anggota rumah tangga, proporsi anggota rumah tangga yang bekerja, jarak ke sekolah, wilayah tempat tinggal, serta faktor perhatian orang tua yang bisa diproksi dari status perkawinan apakah bercerai atau tidak. Penelitian ini bermaksud untuk mengisi kekurangan informasi terkait faktor penentu aksesibilitas anak pada level pendidikan anak usia dini dengan mengacu pada penelitian sebelumnya.

Mengingat di Kabupaten Sumedang, partisipasi sekolah untuk anak usia dini masih rendah maka diperlukan informasi terkait faktor yang mempengaruhi aksesibilitas anak-anak mengikuti pendidikan anak usia dini di Kabupaten Sumedang. Hasil penelitian ini diharapkan bermanfaat bagi pengambil kebijakan dalam merencanakan aspek strategis di bidang pendidikan. Oleh karena itu penelitian ini bertujuan untuk mengetahui faktorfaktor yang diduga mempengaruhi aksesibilitas anak-anak di Kabupaten Sumedang untuk mengikuti 
pendidikan anak usia dini. Hipotesis penelitian ini menduga terdapat perbedaan aksesibilitas anak mengikuti pendidikan anak usia dini dilihat dari perbedaan karakteristik rumah tangga.

\section{METODE PENELITIAN}

\section{Waktu, Lokasi, dan Data}

Penelitian ini dilakukan pada tahun 2017 bertempat di Kabupaten Sumedang. Sumber data yang digunakan merupakan data sekunder yang berasal dari Survei Sosial Ekonomi Nasional (Susenas) tahun 2015 (BPS, 2016b). Unit analisis penelitian ini adalah individu anak usia 4-10 tahun sebanyak 300 orang yang memberikan keterangan keikutsertaan dalam pendidikan anak usia dini. Jenis data adalah cross section.

\section{Model dan Operasionalisasi Variabel}

Model dalam penelitian ini menggunakan beberapa variabel dari penelitian sebelumnya yang relevan dengan permasalahan yang diteliti. Variabel terikat adalah variabel dummy yang bernilai 1 (satu) untuk anak yang pernah atau masih mengikuti pendidikan anak usia dini, dan 0 (nol) untuk anak yang tidak pernah mengikuti pendidikan anak usia dini.

Sementara variabel bebas yang digunakan antara lain gender anak, domisili, pendapatan rumah tangga, jumlah anggota rumah tangga, status perkawinan orang tua, pendidikan kepala rumah tangga, gender kepala rumah tangga, dan status bekerja kepala rumah tangga. Khusus untuk pendidikan kepala rumah tangga, pada peneilitian ini dibedakan berdasarkan tingkatan sekolah formal yang ditamatkan oleh kepala rumah tangga. Model dalam penelitian ini dirumuskan sebagai berikut:

$\mathrm{Yi}=\beta 0+\beta 1$ anak_laki $+\beta 2$ kota + $\beta 3$ pendapatan_RT $+\beta 4$ jumlah_ART $+\beta 5$ ortu_utuh $+\beta 6$ KRT_SD + $\beta 7$ KRT_SLTP + $\beta 8$ KRT_SLTA + $\beta 9 K R T$ pria $+\beta 10 \mathrm{KRT}$ kerja $+\mathrm{Ui}$

Tabel 1

Ringkasan Variabel Penelitian

\begin{tabular}{clc}
\hline No. & Nama variabel & \multicolumn{1}{c}{ Definisi Operasional } \\
\hline A & Terikat & \\
1 & $\begin{array}{l}\mathrm{P}(\mathrm{Y}=1 \mid \mathrm{X}) \text { atau } \\
\text { Dummy }\end{array}$ & $\begin{array}{l}\text { Probabilitas anak mengikuti } \\
\text { pendidikan anak usia dini } \\
1: \text { pernah/masih mengikuti } \\
\text { pendidikan anak usia dini } \\
0 \text { : tidak pernah mengikuti } \\
\text { pendidikan anak usia dini }\end{array}$ \\
& & \\
& & Gender anak: \\
B & Bebas & \\
\hline
\end{tabular}

\begin{tabular}{|c|c|c|}
\hline No. & Nama variabel & Definisi Operasional \\
\hline & & $\begin{array}{l}\text { 1: laki-laki, } \\
0 \text { : perempuan }\end{array}$ \\
\hline 2 & Kota & $\begin{array}{l}\text { Domisili rumah tangga } \\
\text { 1: Kota, 0: Desa }\end{array}$ \\
\hline 3 & Pendapatan_RT & $\begin{array}{l}\text { Pendapatan rumah tangga } \\
\text { selama satu bulan (juta ru- } \\
\text { piah) }\end{array}$ \\
\hline 4 & Jumlah_ART & $\begin{array}{l}\text { Jumlah anggota rumah tang- } \\
\text { ga (orang) }\end{array}$ \\
\hline 5 & Ortu_utuh & $\begin{array}{l}\text { Status Perkawinan orang } \\
\text { tua: } \\
\text { 1: menikah \& tinggal ber- } \\
\text { sama pasangan, } \\
0 \text { : cerai/single parents }\end{array}$ \\
\hline \multirow[t]{4}{*}{6} & Pendidikan KRT & $\begin{array}{l}\text { Tingkat pendidikan kepala } \\
\text { rumah tangga }\end{array}$ \\
\hline & a. KRT_SD & $\begin{array}{l}\text { Dummy untuk level pendidi- } \\
\text { kan kepala rumah tangga SD } \\
1=\text { Tingkat pendidikan ke- } \\
\text { pala rumah tangga SD } \\
0=\text { lainnya }\end{array}$ \\
\hline & b. KRT_SLTP & $\begin{array}{l}\text { Dummy untuk level pendi- } \\
\text { dikan kepala rumah tangga } \\
\text { SLTP } \\
1=\text { Tingkat pendidikan ke- } \\
\text { pala rumah tangga SLTP } \\
0=\text { lainnya }\end{array}$ \\
\hline & c. KRT_SLTA & $\begin{array}{l}\text { Dummy untuk level pendi- } \\
\text { dikan kepala rumah tangga } \\
\text { SLTA } \\
1=\text { Tingkat pendidikan ke- } \\
\text { pala rumah tangga SLTA } \\
0=\text { lainnya }\end{array}$ \\
\hline 7 & KRT_pria & $\begin{array}{l}\text { Gender kepala rumah tangga } \\
\text { 1: laki-laki, } \\
\text { 0: perempuan }\end{array}$ \\
\hline 8 & KRT_kerja & $\begin{array}{l}\text { Status bekerja kepala rumah } \\
\text { tangga } \\
\text { 1: bekerja, } \\
0 \text { : lainnya }\end{array}$ \\
\hline
\end{tabular}

\section{Metode Analisis Data}

Data diolah dengan software STATA versi 12, dan digunakan metode kuantitatif dengan teknik analisis regresi logistik sebagaimana yang dilakukan pada beberapa penelitian terdahulu. Regresi logistik merupakan metode yang sesuai untuk melihat kecenderungan seorang anak mengikuti pendidikan anak usia dini atau tidak dengan menjadikan variabel terikat sebagai variabel dummy yang bersifat binner (memiliki peluang 1 atau 0 ). 


\section{HASIL DAN PEMBAHASAN}

\section{Deskriptif Karakteristik Responden Berdasarkan} Partisipasi Mengikuti Pendidikan Anak Usia Dini

Dari 300 responden yang ada dalam data Susenas tahun 2015 untuk Kabupaten Sumedang, proporsi yang mengikuti pendidikan anak usia dini sebanyak 103 orang atau $34,33 \%$. Sementara anak yang tidak mengikuti pendidikan anak usia dini jumlahnya lebih besar lagi, yaitu sebanyak 197 orang atau $65,67 \%$. Gambar 3, menggambarkan kondisi sosial ekonomi dan demografi dari responden.

Dilihat dari perbedaan gender anak, tidak terlihat perbedaan mencolok antara proporsi anak berjenis kelamin laki-laki dan anak perempuan yang mengikuti pendidikan anak usia dini dengan yang tidak mengikuti pendidikan anak usia dini. Berdasarkan perbedaan domisili atau tempat tinggal, diketahui bahwa di perdesaan jauh lebih banyak anak yang tidak mengikuti pendidikan anak usia dini, sementara di perkotaan, jumlah anak yang tidak mengikuti pendidikan anak usia dini dengan anak mengikuti pendidikan anak usia dini relatif lebih berimbang.

Pendapatan rumah tangga yang dibedakan dengan Upah Minimum Kabupaten (UMK) Sumedang pada tahun 2015 berdasarkan Keputusan Gubernur Jawa Barat Nomor 561/Kep.1581-Bangsos/2014 tentang Upah Minimum Kabupaten/Kota di Jawa Barat Tahun 2015 diketahui bahwa UMK Sumedang dibedakan untuk kawasan industri sebesar Rp. 2.001.195 dan non industri sebesar Rp. 1.270.000. Jika dibedakan berdasarkan UMK yang lebih tinggi yaitu Rp. 2.000.000.- maka sebagian besar responden berada pada rumah tangga dengan pendapatan lebih dari Rp. 2.000.000,-. Namun yang menarik ternyata responden yang pendapatan rumah tangga di bawah UMK masih ada yang mengikuti pendidikan anak usia dini.

Di Kabupaten Sumedang masih banyak rumah tangga yang jumlah anggotanya melebihi 4 orang atau melebihi kriteria ideal yang diprogramkan pemerintah melalui Keluarga Berencana (KB). Namun demikian dari jumlah rumah tangga yang anggotanya melebihi 4 orang masih terdapat anak yang mengikuti pendidikan anak usia dini meskipun tidak sebanyak pada rumah tangga yang anggotanya tidak lebih dari 4 orang.

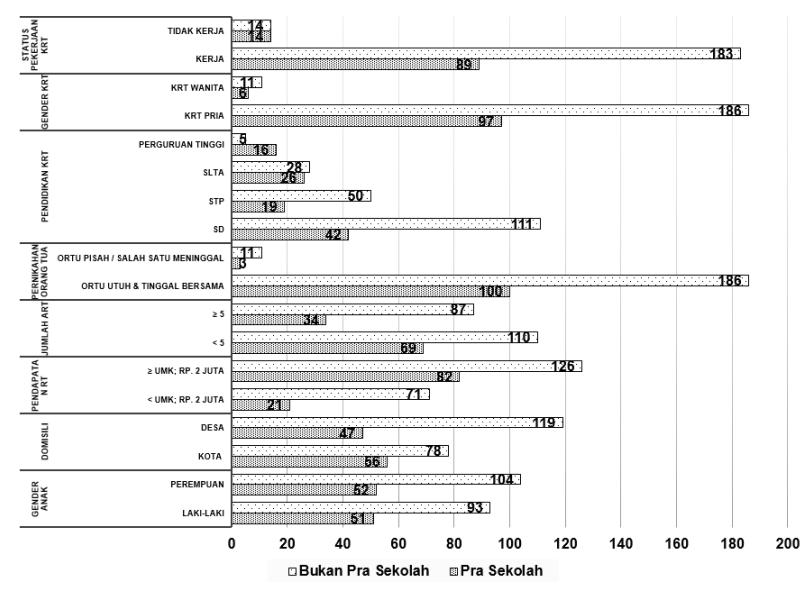

Gambar 3. Karakteristik responden

Responden sebagian besar (95\%) berada atau tinggal pada keluarga yang memiliki orang tua lengkap dan masih tinggal bersama, hanya sebagian kecil saja yang orang tuanya sudah bercerai atau salah satunya meninggal dunia. Namun masih terdapat anak yang mengikuti pendidikan anak usia dini walaupun tidak berada pada keluarga yang utuh.

Pekerjaan kepala rumah tangga dari responden, umumnya, merupakan orang yang bekerja, hanya sebagian kecil saja kepala rumah tangga responden yang tidak bekerja. Adapun berdasarkan gender dari kepala rumah tangga responden, masih didominasi oleh laki-laki dan hanya sebagian kecil yang dipimpin oleh seorang perempuan.

Pendidikan kepala rumah tangga mayoritas merupakan lulusan SD atau sederajat, diikuti oleh lulusan SLTP, SLTA, dan hanya sebagian kecil yang menyelesaikan hingga tingkat perguruan tinggi. Proporsi anak yang mengikuti pendidikan anak usia dini relatif lebih banyak pada kepala rumah tangga yang lebih tinggi tingkat pendidikannya.

\section{Pengujian Statistik dan Analisis Hasil Regresi}

Variabel yang secara statistik signifikan terhadap peluang seorang anak mengikuti pendidikan anak usia dini adalah:

\section{Pendidikan kepala rumah tangga}

Dalam penelitian ini, pendidikan Kepala Rumah Tangga (KRT) merupakan faktor yang paling berpengaruh terhadap partisipasi anak mengikuti pendidikan anak usia dini. Hal ini sesuai dengan hasil penelitian sebelumnya (Aristin, 2015; Fahmi 
\& Jewelery, 2015; Perdana, 2015). Dari marginal effect nya bisa diinterpretasikan bahwa anak dengan KRT berpendidikan dasar dan menengah, memiliki peluang akses yang lebih rendah masing-masing sebesar $25,7 \%$ dan $33,6 \%$ terhadap partisipasi anak mengikuti pendidikan anak usia dini dibandingkan dengan anak dengan KRT berpendidikan perguruan tinggi, asumsi ceteris paribus. Sementara partisipasi anak mengikuti pendidikan anak usia dini anak dengan KRT berpendidikan SLTA tidak berbeda secara signifikan dengan anak yang memiliki KRT berpendidikan tinggi, asumsi ceteris paribus. Kondisi ini mencerminkan bahwa pendidikan orang tua, khususnya kepala rumah tangga memegang peran penting dalam memberikan akses anak terhadap pendidikan anak usia dini.

\section{Pendapatan rumah tangga}

Sesuai hipotesis, variabel pendapatan rumah tangga merupakan salah satu faktor penentu akses anak terhadap pendidikan sebagaimana yang telah dibuktikan pada beberapa penelitian terdahulu (Aristin, 2015; Dewi, Zukhri, \& Dunia, 2014; Perdana, 2015). Hasil pengujian marginal effect dari regresi logit dapat diinterpretasikan bahwa setiap kenaikan pendapatan rumah tangga sebesar Rp. 1 juta maka akan meningkatkan akses anak terhadap pendidikan anak usia dini sebesar $2,7 \%$, asumsi ceteris paribus. Mengingat masih diperlukan biaya untuk mendapat akses kepada pendidikan anak usia dini, maka pendapatan rumah tangga akan sangat menentukan keputusan keluarga untuk menyekolahkan anak mereka di lembaga pendidikan anak usia dini.

\section{Jumlah anggota rumah tangga}

Pada penelitian sebelumnya, diketahui bahwa semakin banyak Anggota Rumah Tangga (ART) atau tanggungan keluarga akan menurunkan aksesibilitas anak bersekolah (Aristin, 2015; Novia Satria Perdana, 2015). Penelitian ini menunjukkan hasil yang sama dimana setiap tambahan satu orang ART akan menurunkan akses anak terhadap pendidikan anak usia dini sebesar $6,1 \%$, asumsi ceteris paribus. Suatu kondisi yang logis jika rumah tangga memiliki banyak anak, apalagi dalam usia sekolah, maka rumah tangga tersebut akan memiliki banyak pertimbangan untuk memprioritaskan pendidikan yang lebih penting bagi anak-anak mereka. Pendidikan usia dini karena bukan termasuk pendidikan dasar yang wajib diterima anak-anak, akan dikorbankan oleh rumah tangga yang memiliki jumlah anak banyak dengan pendapatan yang terbatas.

\section{Status pernikahan orang tua}

Peluang seorang anak untuk bersekolah juga ditentukan oleh status pernikahan orang tuanya. Banyak anak putus sekolah disebabkan kurangnya perhatian orang tua yang lebih sering dijumpai pada anak dengan orang tua yang bercerai (Dewi, Zukhri, \& Dunia, 2014). Penelitian ini membuktikan bahwa anak yang memiliki orang tua lengkap dan tinggal bersama dalam keluarga memiliki akses yang lebih tinggi sebesar 46,6\% terhadap pendidikan anak usia dini dibandingkan anak yang salah satu orang tuanya meninggal atau bercerai, asumsi ceteris paribus. Oleh karena itu, keharmonisan keluarga merupakan faktor penting yang dapat menentukan akses anak terhadap pendidikan anak usia dini.

Domisili

Perbedaan tempat tinggal anak antara perkotaan dan perdesaan pada beberapa penelitian sebelumnya menunjukkan pengaruh yang signifikan terhadap aksesibilitas anak bersekolah. Anak yang berdomisili di perkotaan memiliki akses yang lebih baik untuk bersekolah dibandingkan yang tinggal di perdesaan (Perdana, 2015), bahkan perolehan nilai ujian nasional anak-anak di perkotaan lebih baik dibandingkan anak sekolah di perdesaan (Fahmi \& Jewelery, 2015). Hasil penelitian ini juga membuktikan bahwa anak yang tinggal di perkotaan memiliki akses yang lebih tinggi $11 \%$ dibandingkan anak yang tinggal di perdesaan terhadap pendidikan anak usia dini, asumsi ceteris paribus. Berdasarkan gambar 3, proporsi anak yang mengikuti pendidikan anak usia dini di perkotaan sebesar $41,79 \%$, sementara di perdesaan hanya mencapai $28,31 \%$. Hal ini semakin mengindikasikan bahwa aksesibilitas anak di perkotaan untuk memperoleh pendidikan anak usia dini lebih baik dibandingkan anak-anak yang berada di perdesaan. Selain perlunya edukasi di tingkat orang tua untuk memberikan pendidikan bagi anak-anaknya di usia dini, keterbatasan infrastruktur dan sarana pendidikan di pedesaan perlu ditingkatkan agar akses anak-anak perdesaan terhadap pendidikan anak usia dini lebih meningkat.

Tabel 2

Hasil Regresi Logit

\begin{tabular}{ccc}
\hline Variabel & Koef. Logit & Marginal Effect \\
\hline anak_laki & 0.136 & 0.028 \\
& $(0.262)$ & $(0.053)$ \\
\hline
\end{tabular}




\begin{tabular}{ccc}
\hline Variabel & Koef. Logit & Marginal Effect \\
\hline kota & $0.540^{*}$ & $0.110^{*}$ \\
& $(0.286)$ & $(0.057)$ \\
pendapatan_ & $0.134^{* *}$ & $0.027^{* *}$ \\
RT & & \\
& $(0.066)$ & $(0.013)$ \\
jumlah_ART & $-0.302^{* *}$ & $-0.061^{* *}$ \\
& $(0.128)$ & $(0.025)$ \\
ortu_utuh & $2.297^{* *}$ & $0.466^{* *}$ \\
& $(1.104)$ & $(0.218)$ \\
KRT_SD & $-1.268^{* *}$ & $-0.257^{* *}$ \\
& $(0.525)$ & $(0.103)$ \\
KRT_SLTP & $-1.654^{* * *}$ & $-0.336^{* * *}$ \\
& $(0.557)$ & $(0.107)$ \\
KRT_SLTA & -0.780 & -0.158 \\
& $(0.557)$ & $(0.112)$ \\
KRT_pria & -1.087 & -0.220 \\
& $(0.933)$ & $(0.188)$ \\
KRT_kerja & -0.653 & -0.132 \\
& $(0.454)$ & $(0.091)$ \\
Constant & 0.616 & \\
& $(0.957)$ & \\
\hline chi2 & 38.556 & 38.556 \\
\# of obs. & 300 & 300 \\
\hline Sumb: & &
\end{tabular}

Sumber: (Susesnas, 2015)

Catatan: Standar error dalam tanda kurung

${ }^{*} p<0.1,{ }^{* *} p<0.05,{ }^{* * *} p<0.01$

\section{Temuan Hasil Penelitian}

Salah satu faktor yang cukup signifikan terhadap akses anak memperoleh pendidikan anak usia dini di Kabupaten Sumedang adalah pendapatan rumah tangga. Hal ini berhubungan dengan biaya pendidikan yang masih menjadi salah satu alokasi pengeluaran rumah tangga cukup besar terutama bagi rumah tangga miskin dan rentan miskin. Di samping pengeluaran rumah tangga terbebani oleh biaya pendidikan secara langsung, juga biaya pendukungnya seperti biaya transportasi dan telekomunikasi. Oleh karena itu, agar akses anak terhadap pendidikan anak usia dini menjadi lebih baik, diperlukan alokasi dana Bantuan Operasional Pendidikan (BOP) untuk pendidikan anak usia dini.

Pendidikan orang tua ternyata cukup menentukan seorang anak akan mengikuti pendidikan anak usia dini atau tidak. Orang tua yang berpendidikan tinggi memiliki kecenderungan untuk menyekolahkan anaknya sejak dini. Oleh karena itu, penting untuk memberikan edukasi mengenai tumbuh kembang anak pada orang tua yang tingkat pendidikannya rendah, terutama orang tua yang hanya sampai tingkat pendidikan dasar.

Banyaknya anggota rumah tangga juga menjadi salah satu faktor penentu akses anak terhadap pendidikan anak usia dini. Karena itu, upaya edukasi dan penyuluhan Keluarga Berencana (KB) perlu ditingkatkan untuk menghasilkan generasi yang berkualitas. Peran penting Badan Kependudukan dan Keluarga Berencana Nasional (BKKBN) tidak hanya pada pengendalian jumlah kelahiran, namun juga pada pembinaan keluarga agar mampu menekan angka perceraian karena terbukti pada penelitian ini bahwa keutuhan perkawinan dapat meningkatkan akses anak terhadap pendidikan anak usia dini.

Diperlukan lebih banyak lembaga pendidikan anak usia dini di daerah perdesaan agar kesenjangan akses anak terhadap pendidikan anak usia dini antara penduduk perkotaan dan pedesaan tidak semakin melebar. Upaya ini dapat ditempuh dengan pemberdayaan masyarakat perdesaan di bidang pendidikan, khususnya melalui pembinaan pengkaderan para pendidik anak usia dini sehingga memiliki kepedulian dan kapasitas yang cukup memadai untuk menyelenggarakan pendidikan anak usia dini di masing-masing wilayah.

Gender anak tidak berpengaruh pada aksesibilitasnya untuk memperoleh pendidikan anak usia dini. Hal ini menjadi indikasi yang baik bahwa penyelenggaraan pendidikan sudah lebih inklusif dengan memberikan kesempatan yang sama bagi anak laki-laki maupun perempuan untuk mendapatkan pelayanan pendidikan anak usia dini. Gender kepala rumah tangga juga tidak mempengaruhi kesempatan anak mengikuti pendidikan anak usia dini. Temuan data/angka ini mengindikasikan bahwa tidak terdapat perbedaan perhatian baik kepala rumah tangganya seorang pria maupun wanita untuk memberikan akses pendidikan anak usia dini bagi anak-anaknya. Status bekerja kepala rumah tangga juga tidak mempengaruhi akses anak pada pendidikan anak usia dini disebabkan adanya transfer dari anggota keluarga yang lain, atau bahkan pencari nafkah ada pada pasangan kepala rumah tangga. 


\section{PENUTUP}

\section{Kesimpulan}

Terdapat beberapa faktor yang memengaruhi aksesibilitas anak di Kabupaten Sumedang untuk mengikuti pendidikan anak usia dini, yaitu pendidikan kepala rumah tangga, pendapatan rumah tangga, jumlah anggota rumah tangga, status pernikahan orang tua, dan domisili rumah tangga. Aksesibilitas anak di Kabupaten Sumedang untuk mengikuti pendidikan anak usia dini akan meningkat jika anak tersebut tinggal di perkotaan, terjadi peningkatan pendapatan rumah tangga, memiliki anggota rumah tangga tidak terlalu banyak, tinggal dalam keluarga bersama kedua orang tuanya, dan memiliki kepala rumah tangga yang berpendidikan tinggi. Edukasi tentang pentingnya pendidikan anak usia dini perlu terus ditingkatkan agar menjadi kebutuhan masyarakat dengan melibatkan peran stakeholder.

\section{Saran}

Kepada Pemerintah Kabupaten Sumedang diharapkan dapat meningkatkan penyediaan sarana dan prasarana pendidikan anak usia dini, khususnya di wilayah perdesaan, melakukan program pembinaan intensif pada gugus PAUD yang tersebar di 26 kecamatan untuk mendorong partisipasi masyarakat dalam penyelenggaraan pendidikan anak usia dini.

Untuk stakeholder lainnya yang secara spesifik menggeluti dunia pendidikan, seperti dinas pendidikan, gugus PAUD, dan komunitas penggiat pendidikan usia dini lainnya yang bersifat nonformal maupun informal, disarankan agar lebih intensif dalam memberikan edukasi kepada masyarakat terkait pentingnya pendidikan anak usia dini terutama bagi golongan masyarakat berpendidikan rendah, agar muncul kesadaran untuk mengoptimalkan tumbuh kembang anak-anaknya demi masa depan yang lebih baik. Upaya lain yang diperlukan adalah memperbanyak lembaga pendidikan anak usia dini di setiap wilayah baik yang bersifat formal (Taman kanak-kanak atau raudatul athfal), nonformal (Kelompok bermain atau taman penitipan anak), maupun informal (Pendidikan yang diselenggarakan keluarga atau lingkungan) sesuai dengan pasal 28 Undang-undang Nomor 20 Tahun 2003 tentang Sistem Pendidikan Nasional.

Bagi masyarakat umum, khususnya orang tua yang memiliki anak usia pendidikan anak usia dini, disarankan agar aktif berpartisipasi dalam program pembinaan dan penyelenggaraan pendidikan anak usia dini, termasuk mengikutsertakan anaknya pada lembaga pendidikan anak usia dini di lingkungannya sehingga tercipta suasana kondusif bagi anak untuk tumbuh dan berkembang lebih baik.

\section{DAFTAR PUSTAKA}

Abdulhak, I. (2003). Memposisikan pendidikan anak usia dini dalam sistem pendidikan nasional. Buletin PADU Jurnal IImiah Anak Dini Usia. Jakarta: Dir. PAUD, Dirjend. PLSP, Depdiknas.

Apriana, R. (2009). Hubungan Pendidikan Anak Usia Dini (PAUD) dengan perkembangan kognitif anak usia prasekolah di Kelurahan Tinmojoyo Kecamatan Banyumanik Semarang. Skripsi. Semarang: Universitas Diponegoro.

Aristin, N. F. (2015). Faktor-faktor yang berpengaruh terhadap anak putus sekolah tingkat Sekolah Menengah Pertama (SMP) di Kecamatan Bondowoso. Jurnal Pendidikan Geografi, 20(1). 30-36. doi: http://dx.doi.org/10.17977/ pg.v20i1.5009

Bappeda Kab. Sumedang. (2015). Profil daerah Kabupaten Sumedang. Diakses melalui http:// www.sumedangkab.go.id/
Berlinski, S. G., Galiani, S., \& Gertler, P. (2006). The effect of pre-primary education on primary school performance. Diakses melalui http:// eprints.ucl.ac.uk/15418/

Black, M. M., Walker, S. P., Fernald, L. C. H., Andersen, C. T., DiGirolamo, A. M., Lu, C., ... Grantham-McGregor, S. (2017). Early childhood development coming of age: science through the life course. The Lancet, 389(10064), 77-90. doi: https://doi. org/10.1016/S0140-6736(16)31389-7

BPS. (2016a). Statistik daerah Kabupaten Sumedang 2016. Kabupaten Sumedang: Badan Pusat Statistik Kabupaten Sumedang.

BPS. (2016b). Survey sosial ekonomi nasional. Diakses melalui https://microdata.bps.go.id/ mikrodata/index.php/catalog/769

Chen, Y., \& Feng, S. (2013). Access to public schools 
and the education of migrant children in China. China Economic Review, 26(1), 75-88. doi: https:// doi.org/10.1016/j.chieco.2013.04.007

Dewi, N. A. K., Zukhri, A., \& Dunia, I. K. (2014). Analisis faktor-faktor penyebab anak putus sekolah usia pendidikan dasar di Kecamatan Gerokgak tahun 2012/2013. Jurnal Jurusan Pendidikan Ekonomi, 4(1), 1-12. http:// ejournal.undiksha.ac.id/index.php/JJPE/ article/view/1898

Engle, P. L., Fernald, L. C. H., Alderman, H., Behrman, J., O'Gara, C., Yousafzai, A., ... Iltus, S. (2011). Strategies for reducing inequalities and improving developmental outcomes for young children in low-income and middle-income countries. The Lancet, 378(9799), 1339-1353. doi: https://doi. org/10.1016/S0140-6736(11)60889-1

Fahmi, M., \& Jewelery, P. G. N. (2015). The effect of pre-school education on academic achievement in Indonesia. Working Paper in Economics and Developments Studies, 201505, 1-18. http://ceds.feb.unpad.ac.id/ wopeds/201505.pdf

Finnie, R., \& Mueller, R. E. (2008). The effects of family income, parental education and other background factors on access to postsecondary education in Canada: Evidence from the YITS. SSRN Electronic Journal, 1-52. doi: https://doi.org/10.2139/ssrn.2256114

Heckman, J. (2014). Early childhood development is a smart investment. Diakses melalui https://heckmanequation.org/assets/2014/04/ The20Heckman20Curve_v2.jpg

Kemdikbud. (2017). Data pokok pendidikan. Diakses melalui http://dapo.dikdasmen.kemdikbud. go.id/

Lake, A. (2011). Early childhood development - Global action is overdue. The Lancet, 378(9799), 1277-1278. doi: https://doi. org/10.1016/S0140-6736(11)61450-5

Majzub, R. M., \& Rashid, A. A. (2012). School readiness among preschool children. Procedia - Social and Behavioral Sciences, 46, 3524-3529. doi: https://doi.org/10.1016/j. sbspro.2012.06.098

Mike, I. O., Nakajjo, A., \& Isoke, D. (2008). Socioeconomic determinants of primary school dropout: The logistic model analysis. MPRA Paper, 7851, 1-25. https://mpra.ub.unimuenchen.de/7851/

Musyarofah. (2014). Urgensi pendidikan anak usia dini dalam membangun generasi bangsa yang berkarakter. Al-Fitrah, 9(1), 1-20. http:// ejournal.iain-jember.ac.id/index.php/alfitrah/ article/view/274

Patmonodewo, S. (2003). Pendidikan anak prasekolah (second). Jakarta: PT. Rineka Cipta.

Perdana, N. S. (2015). Faktor-faktor yang berpengaruh terhadap aksesibilitas memperoleh pendidikan untuk anak-anak di Indonesia. Jurnal Pendidikan dan Kebudayaan, 21(3), 279298. doi: http://dx.doi.org/10.24832\%2Fjpnk. v21i3.191

Rahman, H. S. (2005). Pendidikan anak usia dini. Yogyakarta: Galah.

Rao, N., Sun, J., Chen, E., \& Ip, P. (2017). Effectiveness of early childhood interventions in promoting cognitive development in developing countries: A systematic review and meta-analysis. Hong Kong Journal of Paediatrics, 22, 14-25. http://www.hkjpaed. org/pdf/2017;22;14-25.pdf

Syahra, R. (2003). Modal sosial : Konsep dan aplikasi perkembangan konsep modal sosial. Jurnal Masyarakat dan Budaya, 5(1), 1-22. doi: http://dx.doi.org/10.14203/jmb.v5i1.256

Todaro, M. P., \& Smith, S. C. (2011). Pembangunan ekonomi di dunia ketiga (11th ed.). Jakarta: Erlangga.

UNDP. (2015). Work for human development. Diakses melalui http://hdr.undp.org/en/ content/human-development-report-2015work-human-development

Warsilah, H. (2017). Pembangunan inklusif dan kebijakan sosial di Kota Solo Jawa Tengah (Edisi Pert). Jakarta: Yayasan Pustaka Obor Indonesia.

Yoshikawa, H., Weiland, C., Brooks-gunn, J., Burchinal, M. R., Espinosa, L. M., Gormley, W. T., ... Zaslow, M. J. (2013). Investing in our future: The evidence base on preschool education. Society for Research in Child Development, (October), 1-24. https://www. fcd-us.org/assets/2013/10/20Base20on20Pr 
eschool20Education20FINAL.pdf

Yusuf, A. A. (2017). Menyelesaikan darurat nutrisi anak sebagai prasyarat pertumbuhan inklusif. Diakses melalui http://sdgcenter.unpad.ac.id/ menyelesaikan-darurat-nutrisi-anak-sebagaiprasyarat-pertumbuhan-inklusif/ pada tanggal 1 Maret 2018 